ASEAN Journal of Chemical Engineering 2021, Vol. 21, No. 2, 249- 271

\title{
Recent Development of Biomass Conversion using lonic liquid-based Processes
}

\author{
Megawati Zunita * \\ Risha Diah Rhamadhani \\ Department of Chemical Engineering, Faculty of Industrial Technology, Institut Teknologi \\ Bandung, Jalan Ganesha 10, Bandung, West Java, Indonesia, 40132 \\ `e-mail:m.zunita@che.itb.ac.id
}

Submitted 04 October 2021

Revised 15 November 2021 Accepted 21 November 2021

Abstract. The amount of biomass products generated globally increases year after year. Nature produces lignocellulose, which is largely constituted of three components in the following order: cellulose (34-50\%), hemicellulose (15-35\%), and lignin (5-30\%). A promising conversion method known as biomass conversion employs a liquid media-based process to address the issue of an abundance of biomass as waste. Converting biomass with ionic liquid (IL) can address not only environmental issues caused by the abundance of biomass waste but also generate new energy sources or new products with economical selling value. IL can be employed as a green catalyst, solvent, or electrolyte, as well as in a number of conversion processes. In general, 1-alkyl-3-methylimidazolium-based cations are the most commonly used IL types for biomass conversion. The conversion conditions are relatively mild, consisting of a low temperature of around $95-220^{\circ} \mathrm{C}, 1 \mathrm{~atm}$, for 10-240 minutes. This paper review is expected to be a significant reference in the future for the development of other biomass conversion processes.

Keywords: Biomass Conversion, Development Process, lonic Liquid

\section{INTRODUCTION}

One irrefutable reality is that fossil fuels, including natural gas, oil, and coal, are still the primary means of meeting global energy consumption demand. However, science has proven that fossil fuels have many disadvantages, such as being non-recyclable and not environmentally friendly. The energy demand is never balanced between energy consumption and available fossil fuels every year. In 2020, the global energy demand from fossil fuels was recorded at $81.3 \mathrm{Btu}$ and was expected to increase about $7 \%$ in 2022. If the demand keeps increasing each year, then fossil fuels are only enough for 50 years (Zhang et al., 2014). The current problem is not only the shrinkage of fossil fuels but also the abundant emissions (such as fly ash particulate and hazardous gases), which are produced from the conventional fossil fuel combustion process. The greenhouse gases that are released into the atmosphere, such as nitrogen oxide, carbon dioxide, and sulphur oxide, may become the primary cause of global climate change. Both issues then push the desire to develop alternative fuels from nonfossil sources.

Biomass is one of the world's largest resources for fulfilling human wellbeing demands. Compared to other renewable energy sources such as nuclear, wind, hydroelectric, 
solar, and geothermal power, biomass has led the current research and development trend in the search for renewable energy sources to support the deduction of fossil fuels (M. Li et al., 2017).

The biomass source is abundant and includes all kinds of organic matter, plantbased materials and is naturally available worldwide (Xu et al., 2016). The amount of biomass each year is estimated to be 170 billion metric tonnes, with carbohydrates accounting for $75 \%$ of this total, but humans consume only $3-4 \%$ of these compounds for food and non-food purposes(Xu et al., 2016). Biomass production was recorded as eight times greater than the total annual global consumption, placing it fourth below the fossil fuel sources of oil, coal, and natural gas. This trend also affected the demand for biomass sources, which was predicted to be around 10 million to 30 million tonnes by 2030 (Chinnappan et al., 2016). According to the Imperial College Centre for Energy Policy and Technology, the obtainable biologically productive agricultural area is approximately 13 Gha, with approximately 1.5 Gha used to expand arable crops and 4 Gha inhabited by forests. Therefore, 5.5 Gha of land has the capacity to offer biomass feedstock. Biomass which can be converted into new products, must contain intrinsic chemical energy (Chinnappan et al., 2016).

Some kinds of biomass can be used, such as forest biomass, industrial waste, energy crops, and agricultural by-products (Lynam et al., 2012). Although it has been established that biomass resources are abundant and environmentally friendly, their usage presents new challenges, notably in the area of energy generation. In this case, the difference in energy density between fossil fuels and biomass is the main factor. Biomass materials have lower energy density than fossil fuels, so biomass materials produce lower thermal efficiency. This low energy content is due to the low bulk density, high moisture content, and high oxygen content in the raw feedstock, limiting the direct combustion process (Bajwa et al., 2018). Today, people have a high desire to develop green chemistry in converting biomass waste into new products.

Nowadays, researchers and industry place a high value on converting biomass resources into renewable energy sources through environmentally friendly media, a process known as the green process. One of the novels and promising media that has become a trend lately is ionic liquids (ILs). Researchers chose ILs because of their excellent thermal stability, wide electrochemical window, virtually zero vapor pressure, and tuneable features in terms of polarity, hydrophobicity, and solvent miscibility behavior with appropriate modifications to their cations and anions (Zhang et al., 2014; M. Li et al., 2017; Khan et al., 2019; Xu et al., 2016). Because of the unique properties of the ILs, they have been broadly applied in various fields beyond separation, catalysis, photoelectric transformation, and material synthesis. Numerous papers related to biomass conversion in ionic liquid were discovered in the Scopus database, as shown in Fig. 1, leading us to conclude that this field will gain greater interest over time, ushering in a new era of biomass conversion.

Research findings in biomass conversion have already shown that ILs perform better than other conventional organic solvents available. As shown in Fig.2, certain uses of biomass conversion products utilizing ILs solvent have been described.

This year, the exploration of ILS has emerged as a significant and exciting re- 
search topic among scientists. This paper review article compares and contrasts them. This study aimed to give further references and significant points of view on biomass conversion and the role of ILs in academia and industry. The next sections of this paper give a more in-depth analysis.

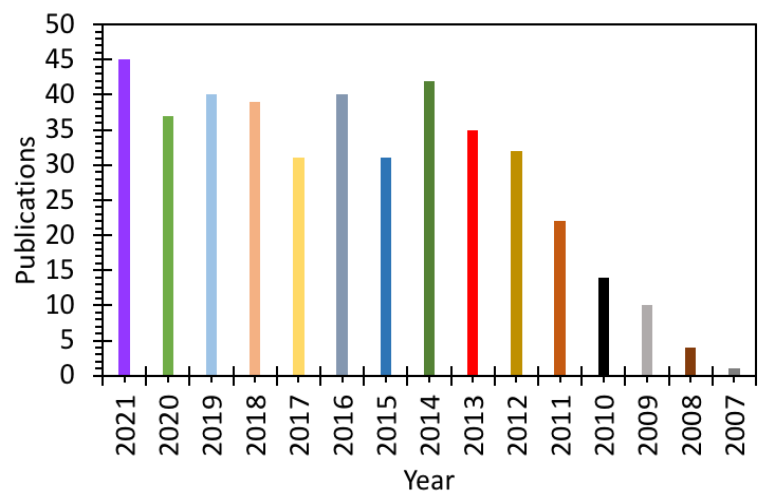

Fig. 1: Annual Number of Publication on Biomass Conversion by lonic-Liquid Method until November 16, 2021; The Search was Conducted from The Data from Scopus with TITLE-ABS-KEY (biomass conversion in ionic liquid)

\section{BIOMASS MATERIAL AS A RESOURCE}

According to the definition, biomass is an organic substance derived from plants or animals. Biomass, which is made up of chemical energy obtained from the sun, has become a source of renewable resources in today's world. There are two main ways to prepare biomass-based energy; firstly, by burning the biomass to produce heat, and secondly, by converting the biomass into renewable liquid and gaseous fuels through various processes (IEA,2020). The production of renewable energy from biomass will surely help reduce the overall world's need for fossil fuel resources. Various biomass products contain energy content, i.e. terpenes, lignin, cellulose, sugars, and vegetable oils (Hartanto et al., 2017). Terpenes have the largest energy content in the sequence, but they have low productivity, which is one of the conditions in the manufacture of biofuels.

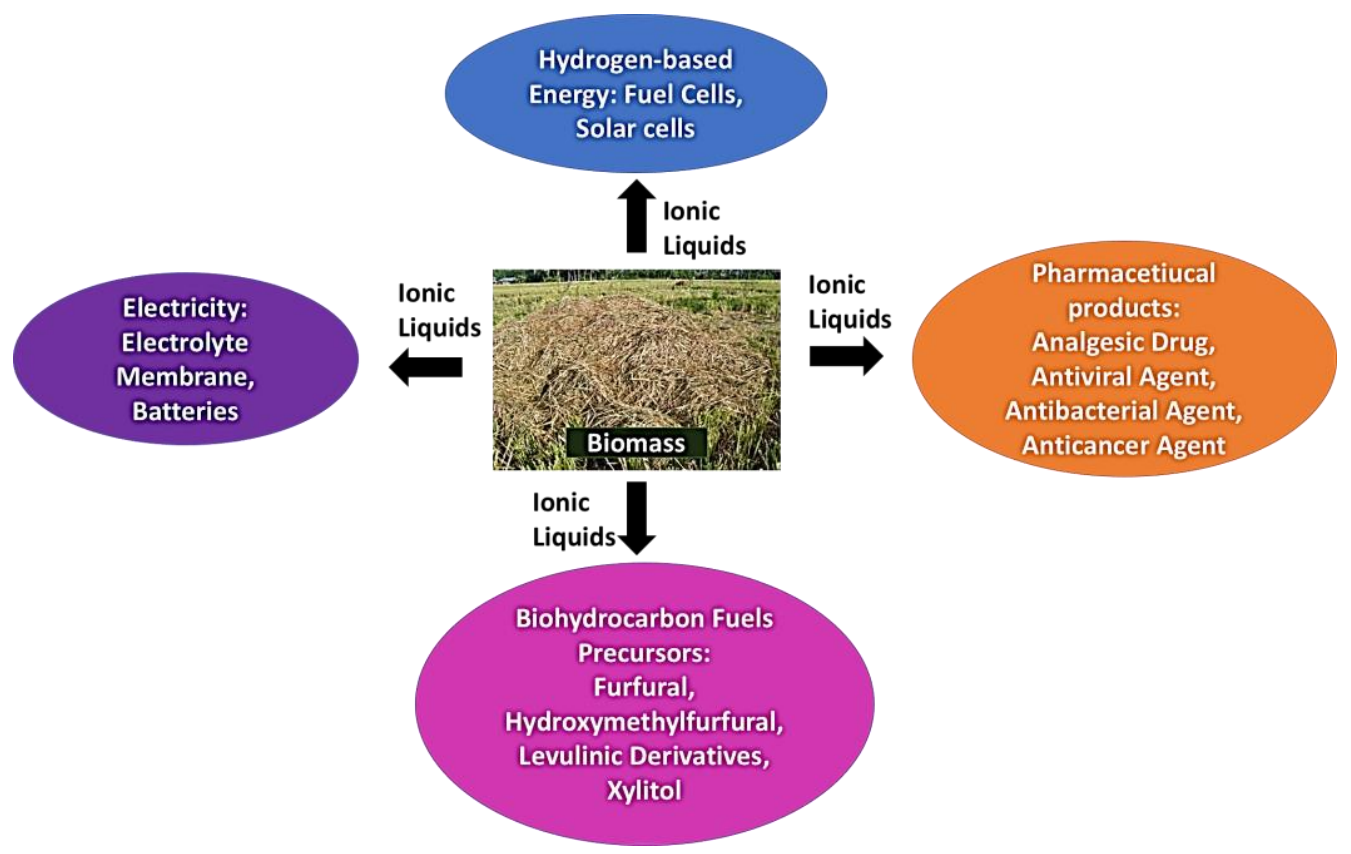

Fig. 2: Various Applications of Biomass Conversion Products from ILs Pretreatment 


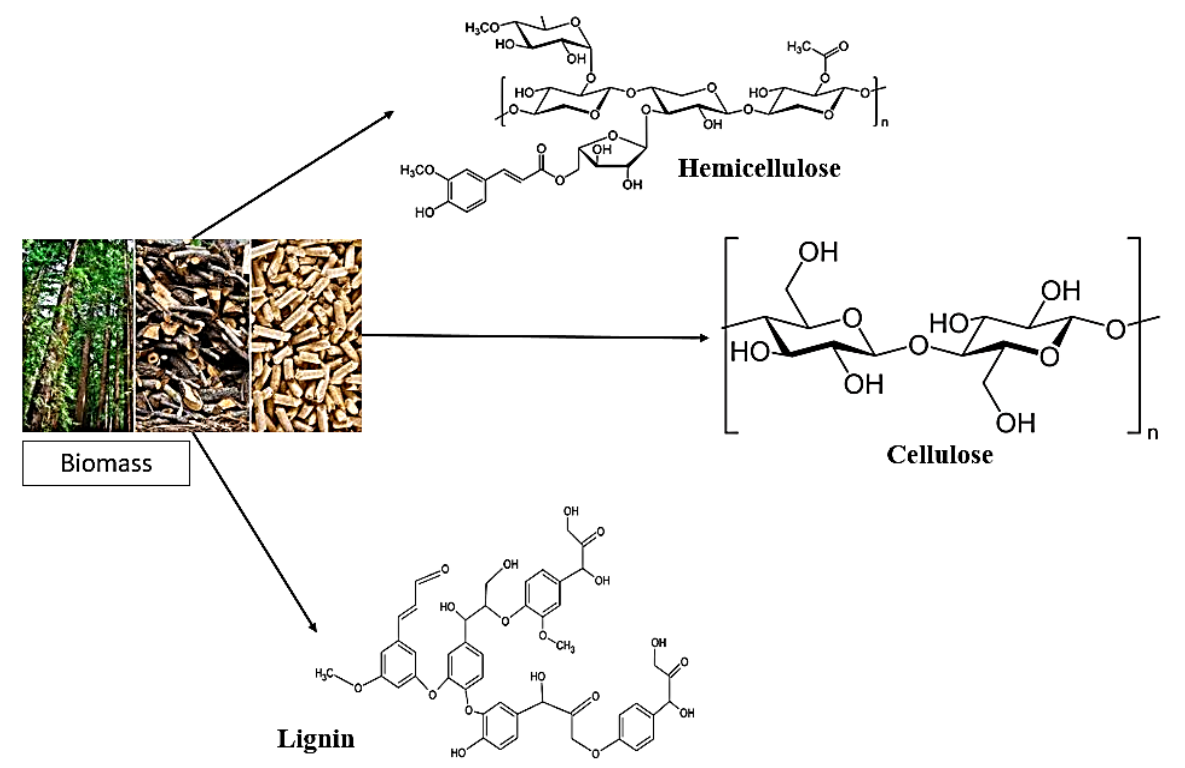

Fig. 3: Content of Biomass Components, adopted from ref. (Xu et al., 2016)

Furthermore, vegetable oils are becoming the next biomass product that could become a potential renewable energy source. The fatty acid in vegetable oils is widely used as sustainable feedstock in some chemical processing industries. However, the production of fatty acids and oleochemicals is prohibited by the volume of oils needed for uneatable use. This limited availability of oils has shown the researchers to use lignocellulosic biomass as a source of renewable energy and chemical feedstock. The primary idea behind biomass conversion is to utilize less hazardous chemicals, enhance the profitability of biorefinery products, and reduce environmental pollution.

Lignocellulosic biomass has become the most relevant biomass component for inquiry in biomass conversion due to the quantity of feedstock worldwide. Lignocellulose is produced by nature. It mainly consists of three components in order; cellulose (34-50\%), hemicellulose (15-35\%), and lignin (5-30\%)
(Xu et al., 2016), as shown in Fig.3. All components were linked to each other by covalent and hydrogen bonds.

Cellulose has become the most widely used ingredient of lignocellulosic biomass because of its promising aspects as a substitute feedstock for the production of biofuel and biochemicals. Cellulose is a homopolymer structure containing glucopyranose repeating units connected by $\beta-(1-4)$ glycosidic bonds. Cellulose chains are arranged as parallel and long chains interlocked through $\mathrm{H}$ bonding and van der Waal forces. The challenge of lignocellulosic conversion is due to the close packing of chains and three-dimensional crystalline structure (Hasanov et al., 2020). The three-dimensional structure contains hydrogen bonding, a high degree of crystallinity, and polymerization, which restrict cellulose's hydrolysis/conversion process into glucose and even other chemicals. 


\begin{tabular}{|c|c|c|c|c|}
\hline Years & Biomass Type & $\begin{array}{l}\text { Biomass } \\
\text { Origin }\end{array}$ & IL Type & Ref. \\
\hline 2012 & Rice Hulls & $\begin{array}{l}\text { Agriculture } \\
\text { waste }\end{array}$ & [EMIM][AC], [AMIM] Cl & $\begin{array}{l}\text { (Lynam et al., } \\
\text { 2012) }\end{array}$ \\
\hline 2013 & Wood Bark & Forest & {$[\mathrm{BMIM}] \mathrm{Cl}$} & $\begin{array}{c}\text { (Ilpeläinen et al., } \\
\text { 2007) }\end{array}$ \\
\hline 2012 & Cassava pulp & $\begin{array}{l}\text { Agriculture } \\
\text { waste }\end{array}$ & [EMIM][AC], [EMIM][DEPO 4$]$ & $\begin{array}{c}\text { (Weerachanchai } \\
\text { et al., 2012) }\end{array}$ \\
\hline 2020 & Sugars & $\begin{array}{l}\text { Agricultural } \\
\text { Waste }\end{array}$ & {$[\mathrm{EMIM}] \mathrm{Cl}$} & $\begin{array}{c}\text { (Ofrasio et al., } \\
\text { 2020) }\end{array}$ \\
\hline \multirow[t]{2}{*}{2017} & Rubber Wood & Plantation & {$[\mathrm{BMIM}] \mathrm{Cl},[\mathrm{BMIM}][\mathrm{Ac}]$} & $\begin{array}{l}\text { (Khan et al., } \\
\text { 2016) }\end{array}$ \\
\hline & Bamboo & Plantation & [EMIM][Gly], [EMIM][TFA] & $\begin{array}{c}\text { (Muhammad et } \\
\text { al., 2011) }\end{array}$ \\
\hline 2007 & Corn Stalk & $\begin{array}{l}\text { Agricultural } \\
\text { Waste }\end{array}$ & $\begin{array}{c}{[\mathrm{SBMIM}]\left[\mathrm{H}_{2} \mathrm{SO}_{4}\right]} \\
{[\mathrm{BMIM}]\left[\mathrm{H}_{2} \mathrm{SO}_{4}\right]}\end{array}$ & $\begin{array}{l}\text { (C. Li \& Zhao, } \\
\text { 2008) }\end{array}$ \\
\hline 2010 & Pine Wood & Forest & $\begin{array}{c}{[\mathrm{SBMIM}]\left[\mathrm{H}_{2} \mathrm{SO}_{4}\right],} \\
{[\mathrm{BMIM}]\left[\mathrm{H}_{2} \mathrm{SO}_{4}\right]}\end{array}$ & $\begin{array}{l}\text { (Brandt et al., } \\
\text { 2010) }\end{array}$ \\
\hline 2007 & Bagasse & $\begin{array}{l}\text { Industrial } \\
\text { Waste }\end{array}$ & $\begin{array}{c}{[\mathrm{SBMIM}]\left[\mathrm{H}_{2} \mathrm{SO}_{4}\right]} \\
{[\mathrm{BMIM}]\left[\mathrm{H}_{2} \mathrm{SO}_{4}\right]}\end{array}$ & $\begin{array}{c}\text { (C. Li \& Zhao, } \\
\text { 2008) }\end{array}$ \\
\hline 2011 & Cotton-waste & Textile Industry & {$[\mathrm{AMIM}] \mathrm{Cl}$} & $\begin{array}{c}\text { (Hong et al., } \\
\text { 2012) }\end{array}$ \\
\hline
\end{tabular}

The main focus of the biomass conversion system is to understand the analysis of the structure and chemical compounds of various biomass feedstocks. Those parameters directly influence the overall yield of the chemical product converted by biomass. As it has a complex structure and strong interaction between all the constituents of cellulosic biomass, it is important to break down the chemical and physical bond first before converting the biomass. Table 1 shows the types of biomass that can be processed into biofuels and biochemicals, along with the types of IL used in the conversion process.

The ultimate challenge of biomass conversion was due to the complex structure and the strong interaction between all the lignocellulosic materials. Four main chemical bonds were available in lignocellulosic materials, i.e. ester, C-C, hydrogen, and ether bond. These bonds connected the individual components (linkage between polymers) and the different constituencies (interpolymer linkage of biomass). The complexity of biomass structural entanglement becomes the cause of difficulties in converting biomass into platform chemicals or even fuels. Thus, researchers have been considering adding a pretreatment method to this conversion to facilitate the conversion of lignocellulosic biomass into platform chemicals. In the next session, the conventional technique of biomass conversion will be discussed before the IL-based processing approach is described. 


\section{BIOMASS CONVERSION USING CONVENTIONAL METHODS}

Researchers have been converting biomass into biofuel and biochemicals using conventional methods before the first publication about converting biomass using ILS was published. Generally, three conventional methods are mostly used in biomass conversion; thermochemical conversion, direct combustion, physio-chemical conversion, and biological conversion (Zunita et al., 2020; Ruya et al., 2020). Each method is mostly used to produce biofuels and biochemicals.

The thermochemical conversion process is the most basic and earliest method of biomass conversion. Pyrolysis, gasification, liquefaction, and combustion are used in the thermochemical conversion process. Direct combustion is the most basic approach. Biomass was converted into heat using this method of burning. All types of biomass are burned directly to generate heat, then utilized to power steam turbines and generate electricity.

The negative of this combustion process is the emission, which is $\mathrm{CO}_{2}$ and $\mathrm{CO}$ (similar to fossil fuel combustion), and the biomass needs to be dried up first before combustion to get maximum yield and efficiency. The emissions from this process are the world's biggest concern since they will affect the overall environmental system. The emissions from this process have become the reason people are looking for another greener method. The next method is thermochemical biomass conversion.

This thermochemical conversion of biomass occurs via gasification, pyrolysis, liquefaction and combustion (Duun et al., 2012).
Pyrolysis and gasification are thermal decomposition processes that use biomass as feedstock material, heated in closely pressurized vessels at high temperatures (around 400$500{ }^{\circ} \mathrm{C}$ ). These two processes can produce biofuels such as bio-oil, biofuel for jet machines and biodiesel.

The next common method is the biochemical method. This biomass conversion method includes two processes, which are anaerobic digestion and fermentation (Naqi et al., 2018). The anaerobic digestion method converts the biomass material directly into biogas and biofertilizer. Meanwhile, the fermentation process produces biochemical products such as bioethanol by adding microorganisms (mostly yeast).

This fermentation process faces a waste problem after the product is obtained. Mostly, even though this waste can be used for other functions, the amount of waste is too much to be handled. Although the fermentation method is simple, it cannot be employed in large-scale biochemical production since it requires massive crops.

There is also one biomass conversion method called microwave irradiation. This method is known to produce high-yield biofuel products from biomass waste (Bundhoo, 2018). Some studies have reported the use of MW irradiation for biomass pretreatment. Microwave irradiation works when waves from the electromagnetic spectrum range from 0.3 to $300 \mathrm{GHz}$. When these microwaves transmit, the waves are transformed into specific frequencies, causing the biomass material to heat up and absorb the waste's energy (Puligundla et al., 2016). 
Table 2. A Comparison of Various Conventional Methods for Biomass Conversion

\begin{tabular}{|c|c|c|c|c|c|}
\hline Method & Process & Product & Condition & Yield & Ref. \\
\hline $\begin{array}{l}\text { Direct } \\
\text { combustion }\end{array}$ & $\begin{array}{l}\text { Convert biomass } \\
\text { into heat }\end{array}$ & $\begin{array}{l}\text { Heat to generate } \\
\text { electricity }\end{array}$ & $\begin{array}{c}\mathrm{T}=\text { maximum } \\
\text { around } 740-1300 \\
{ }^{\circ} \mathrm{C}\end{array}$ & Power and heat & $\begin{array}{l}\text { (Adams et al., } \\
\text { 2018) }\end{array}$ \\
\hline Gasification & $\begin{array}{l}\text { Convert organic feedstock } \\
\text { into gaseous component }\end{array}$ & Syngas & $\begin{array}{l}\mathrm{T}=\text { moderate to } \\
\text { high }(600-1200 \\
\left.{ }^{\circ} \mathrm{C}\right) \text {, small particle } \\
\text { is preferable }\end{array}$ & $\begin{array}{l}\text { Gas yield }\left(\mathrm{m}^{3} / \mathrm{kg}\right. \\
\text { of biomass) }\end{array}$ & $\begin{array}{l}\text { (Adams et al., } \\
\text { 2018) }\end{array}$ \\
\hline $\begin{array}{l}\text { Hydrothermal } \\
\text { Liquefaction }\end{array}$ & $\begin{array}{c}\text { Convert aqueous biomass } \\
\text { slurries with high moisture } \\
\text { content }\end{array}$ & Bio-oil, chemicals & $\begin{array}{l}\mathrm{T}=400-1200^{\circ} \mathrm{C} \\
\text { high pressure }\end{array}$ & Bio oil: $60-75 \%$ & $\begin{array}{l}\text { (Adams et al., } \\
\text { 2018) }\end{array}$ \\
\hline $\begin{array}{l}\text { Biological } \\
\text { conversion }\end{array}$ & $\begin{array}{l}\text { Anaerobic digestion and } \\
\text { fermentation }\end{array}$ & Ethanol & $\begin{array}{c}\text { Fermentation of } \\
\text { biomass by adding } \\
\text { yeast }\end{array}$ & Ethanol: $85 \%$ & $\begin{array}{l}\text { (Adams et al., } \\
\text { 2018); (Naqi, } \\
\text { 2018) }\end{array}$ \\
\hline Microwave & $\begin{array}{l}\text { Irradiating biomass by us- } \\
\text { ing microwave irradiation }\end{array}$ & Biofuels & $\begin{array}{c}\mathrm{T}=333 \mathrm{~K} ; \text { Time: } \\
30 \mathrm{~min}\end{array}$ & $\begin{array}{l}91,4 \% \text { mol of } \\
\text { biofuel }\end{array}$ & $\begin{array}{l}\text { (Bundhoo, } \\
\text { 2018) }\end{array}$ \\
\hline Pyrolysis & $\begin{array}{l}\text { Thermal decomposition of } \\
\text { biomass with the absence } \\
\text { of oxygen }\end{array}$ & $\begin{array}{l}\text { Liquid bio-oil, } \\
\text { chemical feedstock }\end{array}$ & $\begin{array}{l}\mathrm{P} \text { at atmospheric, } \\
\mathrm{T} \text { around } 400-550 \\
{ }^{\circ} \mathrm{C}\end{array}$ & $\begin{array}{l}\text { Liquid bio oil: } \\
\text { 65-75\%; Chemi- } \\
\text { cal feedstock } \\
\text { solid form: } 13- \\
25 \%\end{array}$ & $\begin{array}{l}\text { (Adams et al., } \\
\text { 2018); (Ren et } \\
\text { al., 2020) }\end{array}$ \\
\hline Extraction & Transesterification process & Biodiesel & $\begin{array}{l}\text { Batch reactor } \\
T=298-338 \mathrm{~K}\end{array}$ & $\begin{array}{c}\text { FAME (biodiesel) } \\
97.7 \%\end{array}$ & $\begin{array}{l}\text { (Boz et al., } \\
\text { 2009) }\end{array}$ \\
\hline
\end{tabular}

\section{GENERAL IONIC LIQUIDS ARE USED IN BIOMASS CONVERSION}

In 2002, the application of ILs as cellulose dissolvers was first described (Swatloski et al., 2002). The first publication gained researchers interest in this new field. For the last decades, the exploration of this IL usage has grown rapidly among researchers, as ILs can perform as green solvents to reduce the dependency on toxic and harmful solvents such as organic solvents or chlorinated solvents (Wikes et al., 2003; Jasstorf et al., 2003; Zunita et al., 2020; Zunita et al., 2021). ILs have been explored due to their advantages, such as the high selectivity of impurities in liquid form (Xu et al., 2016). In general, ILs are liquid salts with temperatures under or close to room temperature. The chemical and physical characteristics of ILs can be altered by modifying the cation and anion combinations. (Brandt et al., 2010). Modern ILs mostly consist of organic cations in the form of aliphatic ammonium ions, quartered aromatics, sulfonium, and alkylated phosphonium (Brandt et al., 2011; Zunita et al., 2021). Therefore, ILs are classified as organic or inorganic salts based on the cations and anions that contain the organic or inorganic substance. Fig. 4 shows some representative common cations and anions used in biomass conversion.

Several IL types have been discovered to dissolve cellulose, lignin, hemicellulose, and untreated lignin (Zunita et al., 2021; Brandt et al., 2010; Agrella et al., 2018). ILs can dissolve because the anions and cations can break the strong interaction of internal hydrogen of the 
biomass by providing electron donor or electron acceptor pairs, thus reducing the crystallinity of biomass to facilitate dissolution (Mudhoo et al., 2018). ILs mostly consist of Fig. 4 shows two ILs based on the ion type: anion and cation. Generally, ILs are formulated in the form of bulky 1,3-dialkylimidazolium, alkylammonium, alkylphosphonium, or alkylpyridinium organic cations and inorganic anions such as most frequently $\mathrm{AlCl}_{4}^{-}, \mathrm{BF}_{4}^{-}$or $\mathrm{PF}_{6}^{-}$but also $\mathrm{NO}_{3}^{-}, \mathrm{ClO}_{4}^{-}, \mathrm{CF}_{3} \mathrm{COO}_{2}^{-}, \mathrm{CF}_{3} \mathrm{SO}_{3}^{-}$ or $\mathrm{CH}_{3} \mathrm{COO}^{-}$and other anions. Table 3 demonstrates the features of ILs as well as their application in biomass conversion.

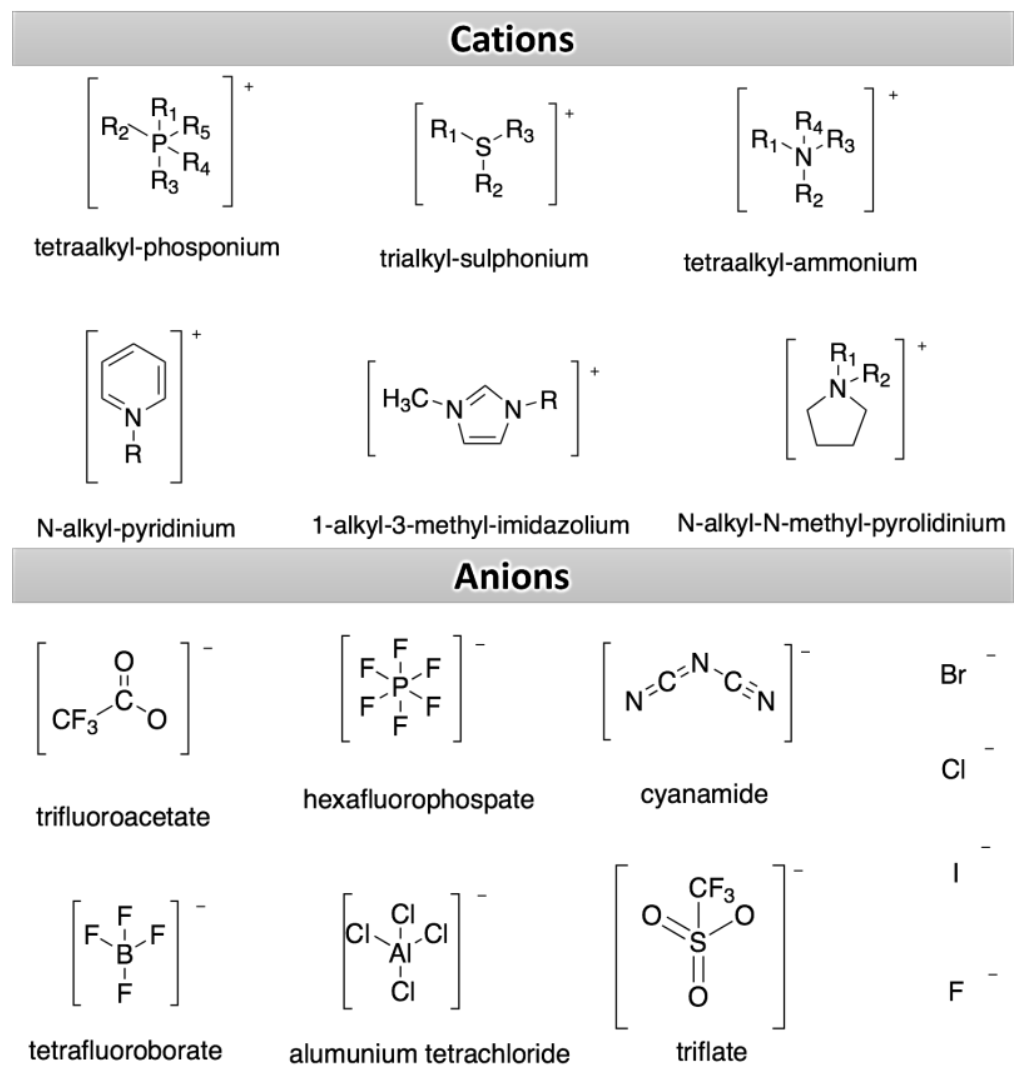

Fig. 4: Some Cations and Anions of ILs are Mostly Used in Biomass Conversion

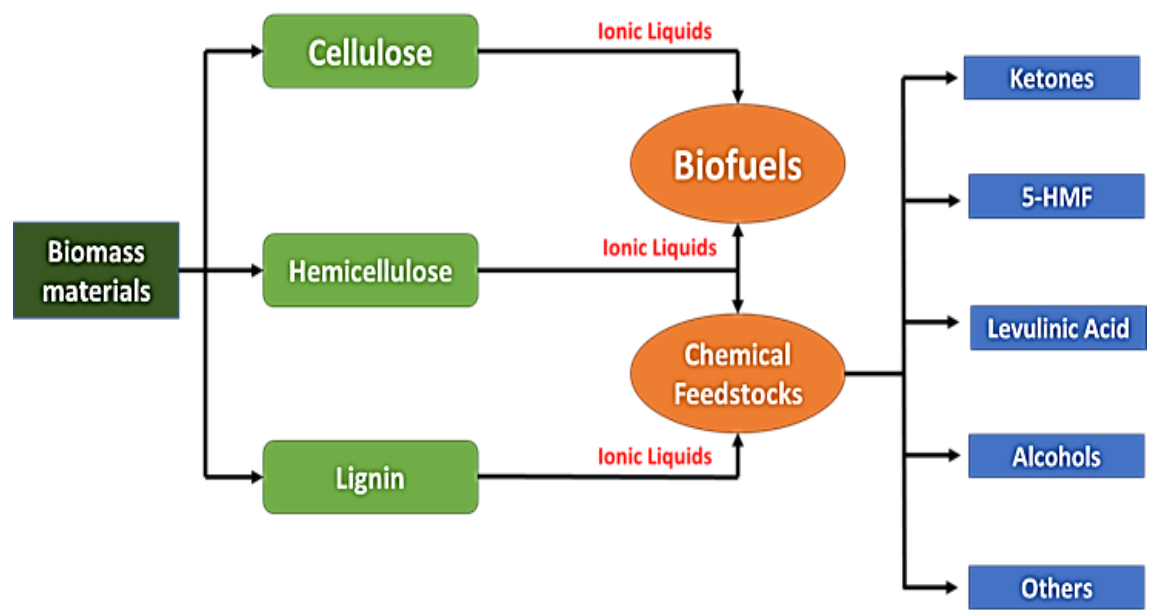

Fig. 1: Potential Products of the Three Major Components of Lignocellulosic Conversion 
Table 3. Properties of Some Most Used ILs

\begin{tabular}{|c|c|c|c|}
\hline IL & Properties & Applications & Ref. \\
\hline [BMIM]Cl & $\begin{array}{c}\rho=1.081 \mathrm{~g} / \mathrm{cm}^{3} \\
\text { Melting point }=65-70{ }^{\circ} \mathrm{C} \\
\text { Soluble in water and organic } \\
\text { solvent }\end{array}$ & $\begin{array}{c}\text { - Glucose Conversion to } \\
\text { 5-HMF } \\
\text { Solvent for Cellulose } \\
\text { conversion to ethanol }\end{array}$ & $\begin{array}{c}\text { (C. Li \& Zhao, 2008); } \\
\text { (Junnienkul et al., 2018) }\end{array}$ \\
\hline [BMIM]Br & $\begin{array}{l}\rho=1.30 \mathrm{~g} / \mathrm{cm}^{3} \\
\text { Melting Point }=65-75^{\circ} \mathrm{C} \\
\text { Boiling point }=547.5^{\circ} \mathrm{C} \\
\text { Miscibility in water }\end{array}$ & $\begin{array}{l}\text { Solvent for sucrose } \\
\text { conversion to 5-HMF }\end{array}$ & $\begin{array}{c}\text { (Chinnappan et al., } \\
\text { 2016); (Kim et al., 2004) }\end{array}$ \\
\hline$[\mathrm{BMIM}]\left[\mathrm{PF}_{6}\right]$ & $\begin{array}{l}\rho=1.36 \mathrm{~g} / \mathrm{cm}^{3} \\
\text { Melting Point }=-8{ }^{\circ} \mathrm{C} \\
\text { Insoluble with water }\end{array}$ & $\begin{array}{l}\text { Solvent for hydrolysis } \\
\text { of } \\
\text { biomass }\end{array}$ & $\begin{array}{c}\text { (Anderson \& } \\
\text { Armstrong, n.d.) }\end{array}$ \\
\hline $\begin{array}{l}\text { [BMIM] } \\
\text { [TfO] }\end{array}$ & $\begin{array}{l}\quad \rho=1.29 \mathrm{~g} / \mathrm{cm}^{3} \\
\text { Melting Point }=16^{\circ} \mathrm{C} \\
\text { Miscibility with water }\end{array}$ & $\begin{array}{l}\text { Solvent to hydrolysis } \\
\text { of biomass }\end{array}$ & $\begin{array}{c}\text { (Anderson \& } \\
\text { Armstrong, n.d.) }\end{array}$ \\
\hline [EMIM]CI & $\begin{array}{l}\quad \rho=1.20 \mathrm{~g} / \mathrm{cm}^{3} \\
\text { Melting point }=77-79{ }^{\circ} \mathrm{C} \\
\text { Boiling point }=484.6^{\circ} \mathrm{C}\end{array}$ & $\begin{array}{c}\text { Glucose conversion to } \\
5-\mathrm{HMF}\end{array}$ & $\begin{array}{c}\text { (Chinnappan et al., } \\
\text { 2016) }\end{array}$ \\
\hline$[\mathrm{BMIM}]\left[\mathrm{BF}_{4}\right]$ & $\begin{array}{l}\rho=1.31 \mathrm{~g} / \mathrm{cm}^{3} \\
\text { Melting point }=-75^{\circ} \mathrm{C} \\
\text { Miscibility in water }\end{array}$ & $\begin{array}{l}\text { Catalyst for fructose } \\
\text { conversion to 5-HMF }\end{array}$ & $\begin{array}{l}\text { (L. Liu et al., } \\
\text { 2018) }\end{array}$ \\
\hline [OMIM]Cl & $\begin{array}{l}\rho=1.00 \mathrm{~g} / \mathrm{cm}^{3} \\
\text { Melting point }=12^{\circ} \mathrm{C} \\
\text { Slightly soluble in water }\end{array}$ & $\begin{array}{l}\text { Solvent for cellulose } \\
\text { conversion to levulinic acid }\end{array}$ & $\begin{array}{l}\text { (L. Liu et al., } \\
\text { 2018) }\end{array}$ \\
\hline
\end{tabular}

\section{THE ROLE OF IONIC LIQUID IN BIOMASS CONVERSION}

Thus far, lignocellulose and derivatives have been converted using ionic liquid to produce HMF, levulinic acid, furfural, formic acid and others, as shown in Fig.5. IL plays a significant role in biomass conversion, particularly as a medium and catalyst. This is assisted by optimal operating parameters (temperature and conversion time) to achieve maximum yield. Because of the high oxygen content in biomass, around $40-45 \%$ of the total, some oxygen section needs to be eliminated in the form of $\mathrm{CO}_{2}$ and $\mathrm{H}_{2} \mathrm{O}$ before converting the lignocellulosic biomass into liquid biofuels. The key topics covered in this section include the role of IL in ethanol synthesis, 5-HMF generation, and levulinic acid production from cellulose.

Li reported that corn stalk in a hydrolyzed form diluted in [BMIM] $\mathrm{Cl}$ and [BMIM] $\left[\mathrm{H}_{2} \mathrm{SO}_{4}\right]$ showed reducing sugar yields of about $68 \%$ and $71 \%$, respectively [91]. Then, the author also dissolved wheat straw in the mixture solvent containing [EMIM][OAC], $[\mathrm{BMIM}] \mathrm{Cl}$, and numerous phosphoric ILs along with 1-ethyl3-methyl imidazolium diethyl phosphate ([EMIM][DEP]), 1-ethyl-3-methyl butylpyridinium diethylphosphate ([EMBy][DEP]), and 1-ethyl-3-methyl imidazolium dibutyl phosphate ([EMIM][DBP]), and it was concluded that $[E M I M][D E P]$ resulted out the highest 
yield of reducing sugars of $50 \%$ after 1 -hour pretreatment process at $100^{\circ} \mathrm{C}$. However, the use of a high concentration of ILs might interrupt the enzyme productivity during the next fermentation process. To support enzyme productivity, it needs a sufficient amount of water. Furthermore, the conversion process of cellulose to ethanol through the fermentation of sugar is an important pretreatment step for the conversion of biomass into biofuel.

\section{Hydroxymethylfurfural from Cellulose}

Hydroxymethylfurfural (5-HMF) is currently popular because it can be converted into building blocks of chemicals that can then be converted into biofuels. It has been done on the hydrogenation, which produces 2,5-dimethylfuran. In addition, the combination of the condensation reaction of $5-\mathrm{HMF}$ and hydrodeoxygenation, which can produce C7-C15 liquid alkanes. ILs work as powerful solvents for the dehydration of monosaccharides to form HMF by breaking the intermolecular hydrogen bonds (Wenten et al., 2019;
Zunita et al., 2020). The scheme of HMF production is presented in Fig. 6 . The ILs also increase the selectivity and recovery of the conversion process of monosaccharides to HMF.

Although 5-HMF has a versatile application, it has not been fully made on an industrial scale due to the high production costs. Zhang et al., 2014 were the first to report that metal halides in the form of [EMIM] $[\mathrm{Cl}]$ are effective catalysts for converting carbohydrates into 5-HMF. Zhang researched the usage effect of plenty of metal halides and a particular number of ILs such as ([BMIM][Cl], $[\mathrm{EMIM}][\mathrm{Cl}],[\mathrm{OMIM}][\mathrm{Cl}])$ on the dehydration reaction of sugars. It is reported that the highest yields for the conversions of fructose and glucose to $5-\mathrm{HMF}$ were $83 \%$ and $70 \%$, respectively. Then, Zhao gained a higher yield when conversing glucose into 5-HMF, about $91 \%$, by using combined ILs chromium salt and $[\mathrm{BMIM}][\mathrm{Cl}]$ underneath microwave irradiation. Besides 5-HMF cellulose, ILs can produce other profitable chemicals such as sorbitol, glucose esters, and 2-5-DMF, which can be directly used as fuels or chemical precursors.
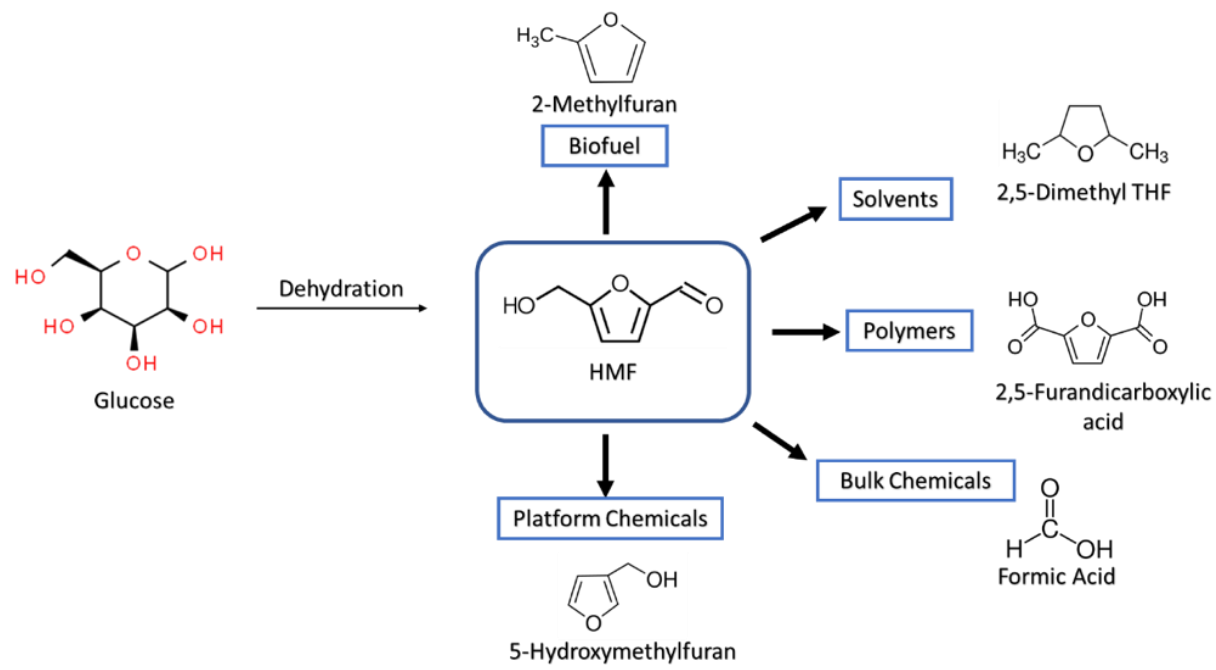

Fig. 6: Scheme of HMF Production from Glucose Conversion 


\section{Levulinic Acid from Hydrolisis of Biomass}

Lignocellulosic biomass to Levulinic Acid (LA). LA mostly works as a viable chemical bridge between the biomass and petroleum cessing industries. LA can be converted into $Y$-valeroactone (GVL), and GVL can be further converted into liquid alkenes via a hydrogenation process, which later has potential value as renewable biofuels. LA is not only becoming a promising basic chemical platform for biofuels but also for other industrial applications such as cosmetics, drug delivery, intermediate chemical resins, the pharmaceutical industry, polymers, and so on (Vaniz et al., 1976).

LA can be produced from several different biomass feedstocks, including polysaccharide families such as starch, hemicellulose, cellulose, and chitin. The hydrolysis process of the feedstock can lead to the production of monosaccharides such as fructose and glucose (Shojaeiarani et al., 2019). The scheme of LA production from biomass conversion is presented in Fig. 7.

Some research has been published on the synthesis of LA using ILs sourced from diverse biomass sources (rice straw, pinewood, maize stalk, and bamboo). In 2018, one report demonstrated that rice straw can produce LA through a one-pot reaction of acidic ILs (i.e., $\left[\mathrm{C}_{3} \mathrm{SO}_{3} \mathrm{HMIM}_{\mathrm{HSO}}\right.$ ) as a catalyst.

Those reactions occur for 30 minutes at $180^{\circ} \mathrm{C}$ and produce LA with a yield of $21 \%$ (Y. Liu et al., 2020). This approach has demonstrated that the interaction between acidic ILS and hydrogen bonding in biomass might lead to a higher yield of LA. The catalyst in this reaction can be recycled up to five times without losing its activity ability. The one-step green conversion of lignocellulosic biomass to LA has paved the way for a promising route in biomass conversion for lignocellulosic feedstocks.

Zunita reported a novel modified IL in 2020 that served as a solvent for producing LA and formic acid (FA). The research focused on a new hydrophobic IL imidazolium-based compound known as 1,3-dipropyl-2-(2propoxyhenyl)-4,5-diphenylimidazolium iodide ([DPDIM]I). In this reported work, the maximum yield obtained from the IL conversion was $94 \%$ LA and $18 \%$ FA with the help of $\mathrm{H}_{2} \mathrm{SO}_{4}$ as catalyst. Zunita also found that in the presence of $\mathrm{H}_{2} \mathrm{SO}_{4}$, [DPDIM] perform better as a solvent than water, and that its performance improves over time.

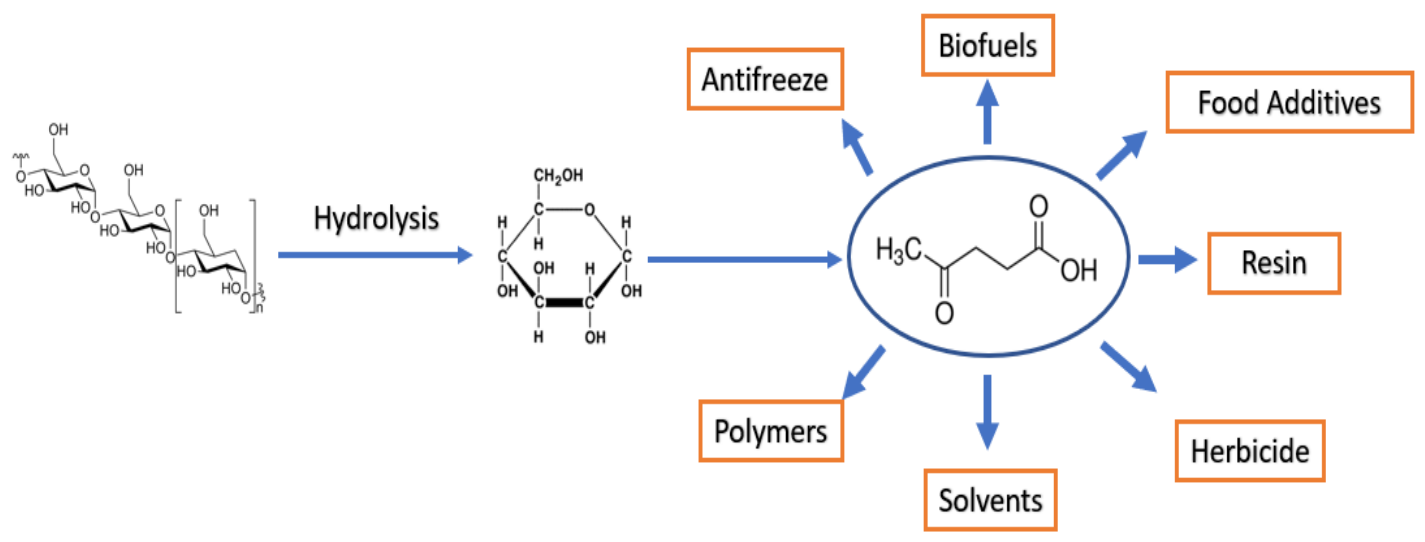

Fig. 7: Basic Scheme on LA Production from Biomass Conversion and Applications 
Table 5. An Overview of Reaction Conditions for the Production of Biochemicals Using Ils

\begin{tabular}{|c|c|c|c|c|c|c|}
\hline Feedstock & ILs & Solvent & Catalyst & $\begin{array}{l}\text { Operating Con- } \\
\text { ditions }\end{array}$ & Yield & Ref. \\
\hline $\begin{array}{l}\text { Sugarcane } \\
\text { bagasse }\end{array}$ & $\begin{array}{c}{\left[\mathrm{BMIMSO}_{3} \mathrm{H}\right]} \\
{\left[\mathrm{HSO}_{4}\right]}\end{array}$ & $\mathrm{H}_{2} \mathrm{O}$ & $\mathrm{H}_{2} \mathrm{SO}_{4}$ & $\begin{array}{c}\mathrm{T}=170^{\circ} \mathrm{C} \\
\text { Time }=75 \mathrm{~min}\end{array}$ & LA, 55\% & $\begin{array}{l}\text { (Zhang et al., } \\
\text { 2014) }\end{array}$ \\
\hline Corn Stalk & $\begin{array}{c}{\left[\mathrm{C}_{4}(\mathrm{MIM})_{2}\right]} \\
{\left[\left(2 \mathrm{HSO}_{4}\right)\right.} \\
\left.\left(\mathrm{H}_{2} \mathrm{SO}_{4}\right)_{4}\right]\end{array}$ & - & - & $\begin{array}{c}\mathrm{T}=95^{\circ} \mathrm{C} \\
\text { Time }=60 \mathrm{~min}\end{array}$ & LA, 70\% & $\begin{array}{l}\text { (Zhang et al., } \\
\text { 2014) }\end{array}$ \\
\hline Sucrose & $\begin{array}{l}\text { [EMIM]Br } \\
{[\mathrm{BMIM}] \mathrm{Br}} \\
{[\mathrm{AMIM}] \mathrm{Cl}}\end{array}$ & {$[\mathrm{NMP}]\left[\mathrm{HSO}_{4}\right]$} & $\mathrm{H}_{2} \mathrm{SO}_{4}$ & $\begin{array}{c}\mathrm{T}=120^{\circ} \mathrm{C} ; \\
\text { Time }=60 \mathrm{~min}\end{array}$ & $\begin{array}{l}5-\mathrm{HMF} \\
72-80 \%\end{array}$ & $\begin{array}{c}\text { (Chinnappan et } \\
\text { al., 2016) }\end{array}$ \\
\hline Fructose & $\begin{array}{c}{[\mathrm{CMIM}][\mathrm{Cl}]} \\
{[\mathrm{BMIM}] \mathrm{OH}} \\
{[\mathrm{BMIM}] \mathrm{Cl}}\end{array}$ & $\begin{array}{c}\text { DMSO } \\
\text { EtOH } \\
\text { Amberlyst-15 }\end{array}$ & - & $\begin{array}{c}\mathrm{T}=160^{\circ} \mathrm{C} \\
\text { Time }=120 \mathrm{~min}\end{array}$ & $\begin{array}{c}5-\mathrm{HMF}, \\
92 \%\end{array}$ & $\begin{array}{c}\text { (Chinnappan et } \\
\text { al., 2016) }\end{array}$ \\
\hline Glucose & 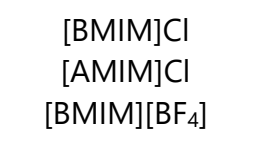 & $\begin{array}{l}\mathrm{IrCl}_{3} \\
\mathrm{CrCl}_{3}\end{array}$ & Boric-acid & $\begin{array}{c}\mathrm{T}=100^{\circ} \mathrm{C} \\
\text { Time }=180 \mathrm{~min}\end{array}$ & $\begin{array}{l}5-\mathrm{HMF}_{1} \\
78,8 \%\end{array}$ & $\begin{array}{c}\text { (Chinnappan et } \\
\text { al., 2016) }\end{array}$ \\
\hline Cellulose & {$\left[\mathrm{C}_{2} \mathrm{MIM}\right][\mathrm{Cl}]$} & $\mathrm{H}_{2} \mathrm{O}$ & $\mathrm{CrCl}_{3}$ & $\mathrm{~T}=120^{\circ} \mathrm{C} ;$ & $\begin{array}{c}5-\mathrm{HMF}, \\
10 \%\end{array}$ & (Hou et al., 2017) \\
\hline Pine Wood & {$\left[\mathrm{C}_{2} \mathrm{MIM}\right] \mathrm{Cl}$} & $\mathrm{H}_{2} \mathrm{O}$ & $\mathrm{CrCl}_{3}$ & $\begin{array}{c}\mathrm{T}=100^{\circ} \mathrm{C} \\
\text { Time }=60 \mathrm{~min}\end{array}$ & $\begin{array}{l}5-\mathrm{HMF} \\
71.6 \%\end{array}$ & $\begin{array}{l}\text { (Brandt et al., } \\
\text { 2010) }\end{array}$ \\
\hline Paddy straw & $\begin{array}{c}{\left[\mathrm{C}_{3} \mathrm{SO}_{3} \mathrm{HMIM}\right][\mathrm{HS}} \\
\left.\mathrm{O}_{4}\right]\end{array}$ & $\mathrm{H}_{2} \mathrm{O}$ & $\mathrm{HCl}$ & $\begin{array}{c}\mathrm{T}=220^{\circ} \mathrm{C} \\
\text { Time }=45 \mathrm{~min}\end{array}$ & LA, $24 \%$ & $\begin{array}{c}\text { (Signoretto et al., } \\
\text { 2019) }\end{array}$ \\
\hline Bamboo & $\begin{array}{c}{\left[\mathrm{C}_{4}(\mathrm{MIM})_{2}\right]} \\
{\left[\left(2 \mathrm{HSO}_{4}\right)\right.} \\
\left.\left(\mathrm{H}_{2} \mathrm{SO}_{4}\right)_{4}\right]\end{array}$ & $\mathrm{H}_{2} \mathrm{O}$ & - & $\begin{array}{c}\mathrm{T}=100^{\circ} \mathrm{C} ; \\
\text { Time }=60 \mathrm{~min}\end{array}$ & LA, $47,5 \%$ & $\begin{array}{c}\text { (Signoretto et al., } \\
\text { 2019) }\end{array}$ \\
\hline Rice Straw & $\begin{array}{c}{\left[\mathrm{C}_{3} \mathrm{SO}_{3} \mathrm{HMIM}\right]} \\
{\left[\mathrm{HSO}_{4}\right]}\end{array}$ & $\mathrm{H}_{2} \mathrm{O}$ & $\begin{array}{l}\mathrm{S}_{2} \mathrm{O}_{8}{ }^{2-} / \mathrm{ZrO}_{2}^{-} \\
\mathrm{SiO}_{2}^{-} \mathrm{Sm}_{2} \mathrm{O}_{3}\end{array}$ & $\begin{array}{c}\mathrm{T}=180^{\circ} \mathrm{C} \\
\text { Time }=10 \mathrm{~min}\end{array}$ & $\begin{array}{c}\text { LA, } 21 \% \\
\text { to } 46 \%\end{array}$ & $\begin{array}{c}\text { (Signoretto et al. } \\
\text { 2019) }\end{array}$ \\
\hline
\end{tabular}

The optimum conditions for this cellulose conversion using ILs solvent [DPDIM]I and $\mathrm{H}_{2} \mathrm{SO}_{4}$ as a catalyst are at a reaction time of $120 \mathrm{~min}$ and a temperature of $140{ }^{\circ} \mathrm{C}$. Furthermore, [DPDIM] can be recycled and reused up to five times (Zunita et al., 2020).

Besides solvents and catalysts, ILs can also be used in the separation process. One of the well-known conventional methods for the separation process is membrane technology (Makertihartha et al., 2017; Zunita, 2021; Zunita et al., 2018). Membrane technology can be combined with ILs to increase the selectivity of the separation process. The method is called the SLM, or supported liquid membrane method (Makertihartha et al., 2017; Zunita et al., 2021; Zunita, 2021).

This combination method works well in a three-phase simultaneous process: extraction from the feed phase to SLM, fluid diffusion through SLM, and re-extraction process in the collected phase. ILs in the SLM can improve the endurance of the membrane technology. Two specific membranes can be easily combined and supported; liquid membrane and hollow fiber (Makertihartha et al., 2017; Makertihartha et al., 2017 ; Zunita et al., 2018). 
Table 6. Comparison of Various ILs on Biomass Conversion Product Yield

\begin{tabular}{|c|c|c|c|c|c|}
\hline ILs & Biomass & $\mathrm{T}\left({ }^{\circ} \mathrm{C}\right)$ & Time(min) & Yield & Ref. \\
\hline [BMIM]Cl & $\begin{array}{l}\text { Cellulose } \\
\text { (bagasse) }\end{array}$ & 100 & 60 & $\begin{array}{l}\text { Reducing sugar } \\
\text { for Ethanol, } 68 \%\end{array}$ & (Zhang et al., 2014) \\
\hline$[\mathrm{BMIM}] \mathrm{Cl}-\mathrm{H}_{2} \mathrm{O}$ & $\begin{array}{c}\text { Cellulose } \\
\text { (Penicillium } \\
\text { janthinellum) }\end{array}$ & 100 & 60 & $\begin{array}{l}\text { Reducing sugar } \\
\text { for ethanol, } 70 \%\end{array}$ & (Zhang et al., 2014) \\
\hline [BMIM]Cl & Sugar & 120 & 30 & HMF, $70-83 \%$ & (Brandt et al., 2011) \\
\hline [EMIM]Cl & Sugar & 120 & 30 & $\mathrm{HMF}, 70 \%$ & (Brandt et al., 2011) \\
\hline [OMIM]Cl & Sugar & 120 & 30 & HMF, $70 \%$ & (Brandt et al., 2011) \\
\hline$\left[\mathrm{C}_{3} \mathrm{SO}_{3} \mathrm{HMIM}\right] \mathrm{H}_{2} \mathrm{PO}_{4}$ & Cellulose & 170 & 300 & LA; $16.7 \%$ & (Khan et al., 2019) \\
\hline$\left[\mathrm{C}_{3} \mathrm{SO}_{3} \mathrm{HMIM} \mathrm{HSO}_{4}\right.$ & Cellulose & 160 & 30 & $L A ; 36,3 \%$ & (Khan et al., 2019) \\
\hline$\left.\left[\mathrm{C}_{4} \mathrm{SO}_{3}\right] \mathrm{HMIM}\right] \mathrm{HSO}_{4}$ & Cellulose & 170 & 300 & $\mathrm{LA} ; 41,4 \%$ & (Khan et al., 2019) \\
\hline$[\mathrm{SMIM}]\left[\mathrm{FeCl}_{4}\right] / \mathrm{H}_{2} \mathrm{O}$ & Glucose & 150 & 240 & $\mathrm{LA} ; 67,8 \%$ & (Aainaa et al., 2015) \\
\hline$[\mathrm{BMIM}]\left[\mathrm{FeCl}_{4}\right] / \mathrm{H}_{2} \mathrm{O}$ & Glucose & 150 & 240 & $L A ; 22,4 \%$ & (Aainaa et al., 2015) \\
\hline$[\mathrm{SMIM}][\mathrm{Cl}] / \mathrm{H}_{2} \mathrm{O}$ & Glucose & 150 & 240 & LA; $25,8 \%$ & (Aainaa et al., 2015) \\
\hline
\end{tabular}

In the case of liquid membranes, ILs were used to support the membrane by covering it with IL. This combination provided some benefits, including low capital and operational costs, low liquid membrane qualification, low energy consumption, and, most significantly, ease of operation (Xu et al., 2016). This SLM method is known to have broad applications involving all kinds of extraction of organic compounds, especially biomass.

\section{PROSPECTS AND CHALLENGES}

Biomass materials, waste, and by-products have been investigated as a viable alternative resource for more than four decades to reduce the world's largest problem in the previous century. This essential study subject is constantly being improved, particularly in terms of the biodegradability of the biomass, which can then be transformed into new biochemical products with a market value.
According to numerous published research, ILs have emerged as a viable and environmentally friendly solvent and catalyst option for enhancing the conversion process of biomass pretreatment. This pretreatment phase in biomass conversion has become critical for increasing the output of bioethanol, LA, or HMF while also increasing the reaction rate. According to several published research, this pretreatment phase is undertaken before beginning the hydrolysis or dehydration process, particularly in the production of LA and HMF. Each type of biomass has its pretreatment procedure determined by the raw component's fundamental state.

These ILs solvents not only break and dissolve cellulose at high concentrations but also be readily recycled after the process, reducing waste. The ILs are referred as green solvents due to their unique characteristics, especially their tunability in polarity, hydrophobicity, and solvent miscibility behaviour, which may be achieved by appropriately modifying their cations and anions. The 1-alkyl-3-methyl-imidazolium halide-based IL is the most promising for use and development in biomass 
conversion. In the future, the tunability features of ILs in biomass conversion will be critical for selecting the best solvent for each type of biomass material.

Despite the numerous and potential advantages of these ILs, there remain difficulties in this sector. The first issue that has always been considered in the usage of ILs is the expense of this process. Essentially, part of the IL's price is exorbitant when compared to ordinary solvent in the laboratory. This is mostly due to the expensive cost of each IL component and the rigorous purification method available. Therefore, the cost of biomass conversion when using $\mathrm{IL}$ as a solvent is 2 to 10 times higher than when using organic solvents, as summarized in Fig. 8. This pricing issue is predicated on carefully selecting the basic cation and anion ILs.

Furthermore, incorporating a recycling process into the entire stage is required to minimize the cost of ILs on an industrial scale. Aside from selecting appropriate ILs, the cost can be reduced by combining existing methods with ILs. This combination approach can enhance product yield because specific conventional techniques have cheaper costs than ILs. The separation and purification of the product solution is the next challenge. Producing a greater yield concentration in the product stream is the best method to address this problem. This approach can assist minimize both the amount of waste solvents and the amount of energy consumed.

According to this review paper, the green synthesis approach, which employs ILs as a solvent, offers a lot of potential for biomass conversion into sustainable products like ethanol and biochemicals. Nonetheless, because of the huge variety of issues that may be researched in the future, this research area is still in its early stages and has a bright future ahead of it.

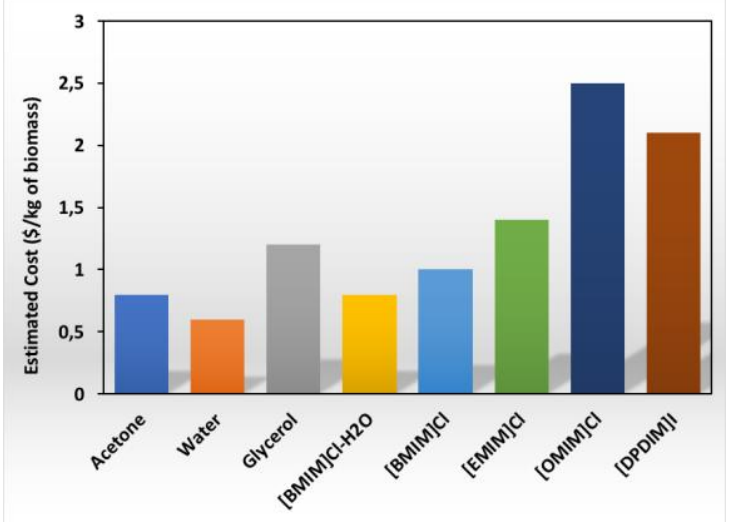

Fig. 8: Cost Comparison of Biomass Conversion Utilizing Organic Solvents and Ionic Liquids. Data Are Collected from (Zunita 2021; Zhang et al., 2014; Brandt et al., 2011).

\section{ACKNOWLEDGEMENTS}

The authors thank Asahi Glass Foundation 2021 and Lembaga Pengelola Dana Penelitian (LPDP) with Contract Number: 20200711012806 for supporting this research.

\section{REFERENCES}

1. Adams, P., Bridgwater, T., Lea-Langton, A., Ross, A., \& Watson, I. (2018). Biomass Conversion Technologies. Report to NNFCC. In Greenhouse Gas Balances of Bioenergy Systems. Elsevier Inc. https://doi.org/10.1016/B978-0-08101036-5.00008-2

2. Agrela, F., Cabrera, M., Morales, M. M., Zamorano, M., \& Alshaaer, M. (2018). Biomass fly ash and biomass bottom ash. In New Trends in Eco-efficient and Recycled Concrete (Vol. 3). https://doi.org/ 10.1016/B978-0-08-102480-5.00002-6

3. Agrela, F., Cabrera, M., Morales, M. M., Zamorano, M., \& Alshaaer, M. (2018). Biomass fly ash and biomass bottom ash. 
In New Trends in Eco-efficient and Recycled Concrete (Vol. 3). https://doi.org/ 10.1016/B978-0-08-102480-5.00002-6

4. Anderson, J. L., \& Armstrong, D. W. (n.d.). in Analytical Chemistry.

5. Asim, A. M., Uroos, M., \& Muhammad, N. (2020). Extraction of lignin and quantitative sugar release from biomass using efficient and cost-effective pyridinium protic ionic liquids. RSC Advances, 10(72), 44003-44014.

https://doi.org/10.1039/d0ra09098k

6. Asim, A. M., Uroos, M., \& Muhammad, N. (2020). Extraction of lignin and quantitative sugar release from biomass using efficient and cost-effective pyridinium protic ionic liquids. RSC Advances, 10(72), 44003-44014.

https://doi.org/10.1039/d0ra09098k

7. Balat, M., Acici, N., \& Ersoy, G. (2006). Trends in the use of biomass as an energy source. Energy Sources, Part B: Economics, Planning and Policy, 1(4), 367378. https://doi.org/10.1080/1556724 0500400705

8. Boz, N., Degirmenbasi, N., \& Kalyon, D. M. (2009). Applied Catalysis B : Environmental Conversion of biomass to fuel : Transesterification of vegetable oil to biodiesel. 89, 590-596. https://doi.org/ 10.1016/j.apcatb.2009.01.026

9. Brandt, A., Hallett, J. P., Leak, D. J., Murphy, J., \& Welton, T. (2010). The effect of the ionic liquid anion in the pretreatment of pine wood chips t. 672-679. https://doi.org/10.1039/b918787a

10. Brandt, A., Hallett, J. P., Leak, D. J., Murphy, R. J., \& Welton, T. (n.d.). Supplementary Information The effect of the ionic liquid anion in the pretreatment of pine wood chips.

11. Brandt, A., Ray, M. J., To, T. Q., Leak, D. J., Murphy, R. J., \& Welton, T. (2011). Ionic liquid pretreatment of lignocellulosic biomass with ionic liquid-water mixtures. Green Chemistry, 13(9), 2489-2499. https://doi.org/10.1039/c1gc15374a

12. Bundhoo, Z. M. A. (2018). Microwave-assisted conversion of biomass and waste materials to biofuels. Renewable and Sustainable Energy Reviews, 82(September 2017), 1149-1177. https://doi.org/ 10.1016/ j.rser.2017.09.066

13. Cao, Y., Yao, S., Wang, X., \& Peng, Q. (2012). T HE P HYSICAL AND C HEMICAL P ROPERTIES OF I ONIC L IQUIDS AND I TS A PPLICATION IN.

14. Chemmangattuvalappil, N. G., Ng, D. K. S., Ng, L. Y., Ooi, J., Chong, J. W., \& Eden, M. R. (2020). A review of process systems engineering (PSE) tools for the design of ionic liquids and integrated biorefineries. Processes, 8(12), 1-29. https://doi.org/ 10.3390/pr8121678

15. Chinnappan, A., \& Baskar, S. (2017). Conversion of Sugars Into 5-Hmf. 123-130.

16. Chinnappan, A., Baskar, C., \& Kim, H. (2016). Biomass into chemicals: Green chemical conversion of carbohydrates into 5-hydroxymethylfurfural in ionic liquids. RSC Advances, 6(68), 63991-64002. https://doi.org/10.1039/c6ra12021k

17. Connor, R. O. (2014). ( 12 ) Patent Application Publication ( 10 ) Pub . No .: US 2014 / 0308720 A1. 1(19).

18. D.M. Alonso, S.G. Wettstein, J.A. Dumesic, Gamma-valerolactone, a sustainable platform molecule derived from lignocellulosic biomass, Green Chem. 15 (2013) 584-595.

19. Dunn, P. J. (2012). The importance of green chemistry in process research and development. Chemical Society Reviews, 41(4), 1452-1461. https://doi.org/ $10.1039 / \mathrm{c} 1 \mathrm{cs} 15041 \mathrm{c}$ 
20. Financie, R., Moniruzzaman, M., \& Uemura, Y. (2016). Enhanced enzymatic delignification of oil palm biomass with ionic liquid pretreatment. Biochemical Engineering Journal, 110, 1-7. https://doi.org/10.1016/j.bej.2016.02.00 8

21. Grza, A., \& Skrzypczak, A. (2019). The influence of the cation type of ionic liquid on the production of nanocrystalline cellulose and mechanical properties of chitosan-based biocomposites. 1, 48274840. https://doi.org/10.1007/s10570019-02412-1

22. Guragain, Y. N., Herrera, A. I., Vadlani, P. V., \& Prakash, O. (2015). Lignins of bioenergy crops: A review. Natural Product Communications, 10(1), 201-208. https: //doi.org/10.1177/1934578x150100014 1

23. Harriman, A. (2013). Prospects for conversion of solar energy into chemical fuels: The concept of a solar fuels industry. Philosophical Transactions of the Royal Society A: Mathematical, Physical and Engineering Sciences, 371(1996). https://doi.org/10.1098/rsta.2011.0415

24. Harriman, A. (2013). Prospects for conversion of solar energy into chemical fuels: The concept of a solar fuels industry. Philosophical Transactions of the Royal Society A: Mathematical, Physical and Engineering Sciences, 371(1996). https://doi.org/10.1098/rsta.2011.0415

25. Hartanto, Y., Yaswari, Y., Zunita, M., Soerawidjaja, T. H., \& Indarto, A. (2017). Decolorization of crude terpineol by adsorption. Separation Science and Technology (Philadelphia), 52(12), 19671972. https://doi.org/10.1080/01496395. 2017.1313863
26. Hasanov, I., Raud, M., \& Kikas, T. (2020). The role of ionic liquids in the lignin separation from lignocellulosic biomass. Energies, 13(18), 1-24. https://doi.org/ 10.3390/en13184864

27. Hina, S., Zhu, X., Chen, Y., \& Zhang, Y. (2015). Chemical Engineering Thermodynamics NU SC Graphic Abstract. CJCHE. https://doi.org/ 10.1016/j.cjche.2014.06.039

28. Hong, F., Guo, X., Zhang, S., Han, S., Yang, G., \& Jönsson, L. J. (2012). Bioresource Technology Bacterial cellulose production from cotton-based waste textiles: Enzymatic saccharification enhanced by ionic liquid pretreatment. Bioresource Technology, 104, 503-508. https:// doi.org/10.1016/j.biortech.2011. 11.028

29. Hou, Q., Ju, M., Li, W., Liu, L., Chen, Y., Yang, Q., \& Zhao, H. (2017). Pretreatment of lignocellulosic biomass with ionic liquids and ionic liquid-based solvent systems. Molecules, 22(3), 1-24. https://doi.org/10.3390/molecules22030490

30. Ilpeläinen, I. L. K., Ie, H. A. X., Ing, A. L. K., Ranstrom, M. A. R. I. G., Eikkinen, S. A. M. I. H., \& Rgyropoulos, D. I. S. A. (2007). Dissolution of Wood in Ionic Liquids. 9142-9148.

31. Julien, P. A., Fri, T., \& Julien, P. (2017). Deconstruction of lignocellulosic biomass with ionic liquids. Green Chem., 207890, 2729-2747.

32. Junnienkul, N., Sriariyanun, M., Douzou, T., Yasurin, P., \& Asavasanti, S. (2018). Optimization of Alkyl Imidazolium Chloride Pretreatment on Rice Straw Biomass Conversion. KMUTNB International Journal of Applied Science and Technology, June. https:// doi.org/10.14416/j.ijast. 2018.06.002 
33. Khan, A. S., Man, Z., Bustam, M. A., Kait, C. F., Ullah, Z., Nasrullah, A., Khan, M. I., Gonfa, G., Ahmad, P., \& Muhammad, N. (2016). SC. Journal of Molecular Liquids. https://doi.org/10.1016/j.molliq.2016.09.012

34. Khan, A. S., Man, Z., Bustam, M. A., Nasrullah, A., Ullah, Z., Sarwono, A., Shah, F. U., \& Muhammad, N. (2018). Efficient conversion of lignocellulosic biomass to levulinic acid using acidic ionic liquids. Carbohydrate Polymers, 181, 208-214. https://doi.org/10.1016/j.carbpol.2017.10.064

35. Khan, A. S., Man, Z., Nasrullah, A., Ullah, Z., Muhammad, N., Rahim, A., Bustam, A., \& Idris, A. (2019). Conversion of biomass to chemicals using ionic liquids. In Green Sustainable Process for Chemical and Environmental Engineering and Science: Ionic Liquids as Green Solvents. Elsevier Inc. https://doi.org/10.1016/B978-0-12817386-2.00001-9

36. Kim, K., Shin, B., \& Lee, H. (2004). Physical and Electrochemical Properties of 1-Butyl-3-methylimidazolium Bromide ,. 21(5), 1010-1014.

37. Krishnan, S., Quraishi, K. S., Aminuddin, N. F., Mazlan, F. A., \& Leveque, J. M. (2016). Biodegradability of immidazolium, pyridinium, piperidinium and pyrrolidinium based ionic liquid in different water source. AIP Conference Proceedings, 1787. https://doi.org/ 10.1063/ 1.4968096

38. KS, R., Ramya, C., \& Varjani, S. (2019). Trends and advances in bioenergy production and sustainable solid waste management. Energy and Environment. https://doi.org/10.1177/0958305X19882 415

39. Kumar, K., Pathak, S., \& Upadhyayula, S. (2020). 2nd generation biomass derived glucose conversion to 5-hydroxymethylfurfural and levulinic acid catalyzed by ionic liquid and transition metal sulfate: Elucidation of kinetics and mechanism. Journal of Cleaner Production, 256, 120292. https:// doi.org/10.1016/j.jclepro.2020.120292

40. Kunz, W., \& Häckl, K. (2016). The hype with ionic liquids as solvents. Chemical Physics Letters, 661, 6-12. https:// doi.org/10.1016/j.cplett.2016.07.044

41. Labbé, N., Kline, L. M., Moens, L., Kim, K., Kim, P. C., \& Hayes, D. G. (2012). Activation of lignocellulosic biomass by ionic liquid for biorefinery fractionation. Bioresource Technology, 104, 701-707. https://doi.org/10.1016/j.biortech.2011. 10.062

42. Labbé, N., Kline, L. M., Moens, L., Kim, K., Kim, P. C., \& Hayes, D. G. (2012). Activation of lignocellulosic biomass by ionic liquid for biorefinery fractionation. Bioresource Technology, 104, 701-707. https://doi.org/10.1016/j.biortech.2011. 10.062

43. Lan, K., Park, S., \& Yao, Y. (2019). Key issue, challenges, and status quo of models for biofuel supply chain design. In Biofuels for a More Sustainable Future: Life Cycle Sustainability Assessment and Multi-Criteria Decision Making. Elsevier Inc. https://doi.org/10.1016/B978-0-12815581-3.00010-5

44. Lan, K., Park, S., \& Yao, Y. (2019). Key issue, challenges, and status quo of models for biofuel supply chain design. In Biofuels for a More Sustainable Future: Life Cycle Sustainability Assessment and Multi-Criteria Decision Making. Elsevier Inc. https://doi.org/10.1016/B978-0-12815581-3.00010-5

45. Li, C., \& Zhao, Z. K. (2008). Acid in ionic liquid: An efficient system for hydrolysis 
of lignocellulose. 177-182. https:// doi.org/10.1039/b711512a

46. Li, M., Luo, N., \& Lu, Y. (2017). Biomass energy technological paradigm (BETP): Trends in this sector. Sustainability (Switzerland), 9(4), 1-28. https://doi.org/ $10.3390 /$ su9040567

47. Liu, D. D. J., \& Chen, E. Y. X. (2013). Polymeric ionic liquid (PIL)-supported recyclable catalysts for biomass conversion into HMF. Biomass and Bioenergy, 48(II), 181-190. https:// doi.org/10.1016/j.biombioe.2012.11.020

48. Liu, L., Li, Z., Hou, W., \& Shen, H. (2018). Direct conversion of lignocellulose to levulinic acid catalyzed by ionic liquid. Carbohydrate Polymers, 181(November 2017), 778-784. https://doi.org/ 10.1016/j.carbpol.2017.11.078

49. Liu, Y., Wu, Y., Su, M., Liu, W., Li, X., \& Liu, F. (2020). Developing Brønsted-Lewis acids bifunctionalized ionic liquids based heteropolyacid hybrid as high-efficient solid acids in esterification and biomass conversion. Journal of Industrial and Engineering Chemistry, 92, 200-209. https: //doi.org/10.1016/j.jiec.2020.09.005

50. Liu, Y., Wu, Y., Su, M., Liu, W., Li, X., \& Liu, F. (2020). Developing Brønsted-Lewis acids bifunctionalized ionic liquids based heteropolyacid hybrid as high-efficient solid acids in esterification and biomass conversion. Journal of Industrial and Engineering Chemistry, 92, 200-209. https: //doi.org/10.1016/j.jiec.2020.09.005

51. Luque, R., De, S., \& Balu, A. M. (2016). Catalytic conversion of biomass. Catalysts, 6(10), 10-11. https://doi.org/ 10.3390/catal6100148

52. Lynam, J. G., Toufiq Reza, M., Vasquez, V. R., \& Coronella, C. J. (2012). Pretreatment of rice hulls by ionic liquid dissolution. Bioresource Technology, 114, 629-636. https://doi.org/10.1016/j.biortech.2012. 03.004

53. Makertihartha, I. G. B. N., Dharmawijaya, P.T., Zunita, M., \& Wenten, I.G. (2017). Post combustion $\mathrm{CO}_{2}$ capture using zeolite membrane. AIP Conference Proceedings, 1818. https://doi.org/10.1063/ 1.4979941

54. Makertihartha, I. G. B. N., Rizki, Z., Zunita, M., \& Dharmawijaya, P. T. (2017). Dyes removal from textile wastewater using graphene based nanofiltration. AIP Conference Proceedings, 1840, 110006. https://doi.org/10.1063/1.498233

55. Makertihartha, I. G. B. N., Zunita, M., Rizki, Z., \& Dharmawijaya, P. T. (2017). Solvent extraction of gold using ionic liquid based process. AIP Conference Proceedings, 1805 . https://doi.org/ $10.1063 / 1.4974419$

56. Makertihartha, I. G. B. N., Zunita, M., Rizki, Z., \& Dharmawijaya, P. T. (2017). Supported ionic liquid membrane in membrane reactor. AIP Conference Proceedings, 1788, 040003 . https:// doi.org/10.1063/1.4968391

57. Mehrdadfar1, A., \&, Majid Amidpour2, N. B. and A. A. S. (2016). World Bioenergy Congress and Expo. Journal of Fundamentals of Renewable Energy and Applications, 6(3), 4541.

58. Mehrdadfar1, A., \&, Majid Amidpour2, N. B. and A. A. S. (2016). World Bioenergy Congress and Expo. Journal of Fundamentals of Renewable Energy and Applications, 6(3), 4541.

59. Mudhoo, A., Torres-Mayanga, P. C., Forster-Carneiro, T., Sivagurunathan, P., Kumar, G., Komilis, D., \& Sánchez, A. (2018). A review of research trends in the enhancement of biomass-to-hydrogen conversion. Waste Management, 79, 
580-594. https://doi.org/10.1016/j.wasman.2018.08.028

60. Muhammad, N., Man, Z., Bustam, M. A., Mutalib, M. I. A., Wilfred, C. D., \& Rafiq, S. (2011). Dissolution and Delignification of Bamboo Biomass Using Amino AcidBased lonic Liquid. 998-1009. https://doi.org/10.1007/s12010-0119315-y

61. N.A.S. Ramli, N.A.S. Amin, A new functionalized ionic liquid for efficient glucose conversion to 5-hydroxymethyl furfural and levulinic acid, J. Mol. Catal. A Chem. 407 (2015) 113-121.

62. Naqi, A. (2018). Conversion of Biomass to Liquid Hydrocarbon Fuels via Anaerobic Digestion: A Feasibility Study. ProQuest Dissertations and Theses, March, 114.

63. Nargotra, P., Sharma, V., Gupta, M., Kour, S., \& Bajaj, B. K. (2018). Application of ionic liquid and alkali pretreatment for enhancing saccharification of sunflower stalk biomass for potential biofuel-ethanol production. Bioresource Technology, 267(May), 560-568. https://doi.org/ 10.1016/j.biortech.2018.07.070

64. Naz, S., Uroos, M., Asim, A. M., Muhammad, N., \& Shah, F. U. (2020). One-Pot Deconstruction and Conversion of Lignocellulose Into Reducing Sugars by Pyridinium-Based Ionic Liquid-Metal Salt System. Frontiers in Chemistry, 8(April), 1-11. https://doi.org/10.3389/ fchem. 2020.00236

65. Naz, S., Uroos, M., Asim, A. M., Muhammad, N., \& Shah, F. U. (2020). One-Pot Deconstruction and Conversion of Lignocellulose Into Reducing Sugars by Pyridinium-Based Ionic Liquid-Metal Salt System. Frontiers in Chemistry, 8(April), 1-11. https://doi.org/ 10.3389/fchem. 2020.00236
66. Naz, S., Uroos, M., Asim, A. M., Muhammad, N., \& Shah, F. U. (2020). One-Pot Deconstruction and Conversion of Lignocellulose Into Reducing Sugars by Pyridinium-Based Ionic Liquid-Metal Salt System. Frontiers in Chemistry, 8(April), 1-11. https://doi.org/ 10.3389/fchem. 2020.00236

67. Ofrasio, B. I. G., de Luna, M. D. G., Chen, Y. C., Abarca, R. R. M., Dong, C. Di, \& Chang, K. L. (2020). Catalytic conversion of sugars and biomass to furanic biofuel precursors by boron-doped biochar in ionic liquid. Bioresource Technology Reports, 11(July), $100515 . \quad$ https:// doi.org/10.1016/j.biteb.2020.100515

68. P. Dhurjati, Biorefineries-industrial processes and products, status quo and future directions:volumes 1 and 2 by Birgit Kamm, Patrick Gruber and Michael Kamm, AICHE J. 54 (2008) 3036.

69. Perea-Moreno, M. A., Samerón-Manzano, E., \& Perea-Moreno, A. J. (2019). Biomass as renewable energy: Worldwide research trends. Sustainability (Switzerland), 11(3). https://doi.org/10.3390/ su11030863

70. Perea-Moreno, M. A., Samerón-Manzano, E., \& Perea-Moreno, A. J. (2019). Biomass as renewable energy: Worldwide research trends. Sustainability (Switzerland), 11(3). https://doi.org/10.3390/ su11030863

71. Puligundla $P$, Oh SE, Mok C. Microwaveassisted pretreatment technologies for the conversion of lignocellulosic biomass to sugars and ethanol: a review. Carbon Lett2016;17:1-10.

72. R.E. Quiroz-Castañeda, J.L. Folch-Mallol, Hydrolysis of biomass mediated by cellulases for the production of sugars, in: Sustainable Degradation of Lignocellulosic 
73. Ren, X. Y., Feng, X. B., Cao, J. P., Tang, W., Wang, Z. H., Yang, Z., Zhao, J. P., Zhang, L. Y., Wang, Y. J., \& Zhao, X. Y. (2020). Catalytic Conversion of Coal and Biomass Volatiles: A Review. Energy and Fuels, 34(9), 10307-10363. https://doi.org/10.1021/acs.energyfuels.0c01432

74. Rogers, R. D., \& Macfarlane, D. (n.d.). Ionic Liquids web themed issue. https://doi.org/10.1039/c2cc30357d

75. Ruya, P.M., Lim, S.S., Purwadi, R., \& Zunita, M. (2020). Sustainable hydrogen production from oil palm derived wastes through autothermal operation of supercritical water gasification system. Energy, 208, 118280. https://doi.org/ 10.1016/j.energy.2020.118280

76. Segneanu, A.-E., Sziple, F., Vlazan, P., Sfarloaga, P., Grozesku, I., \& Daniel, V. (2013). Biomass Extraction Methods. Biomass Now - Sustainable Growth and Use. https://doi.org/10.5772/55338

77. Shojaeiarani, J., Bajwa, D. S., \& Bajwa, S. G. (2019). Properties of densified solid biofuels in relation to chemical composition, moisture content, and bulk density of the biomass. BioResources, 14(2), 4996-5015. https://doi.org/ 10.15376/biores.14.2.Shojaeiarani

78. Shojaeiarani, J., Bajwa, D. S., \& Bajwa, S. G. (2019). Properties of densified solid biofuels in relation to chemical composition, moisture content, and bulk density of the biomass. BioResources, 14(2), 4996-5015. https://doi.org/ 10.15376/biores.14.2.Shojaeiarani

79. Signoretto, M., Taghavi, S., Ghedini, E., \& Menegazzo, F. (2019). Actual. 1-20.

80. Sowmiah, S., Esperança, J. M. S. S., Rebelo, L. P. N., \& Afonso, C. A. M. (2018). Pyridinium salts: From synthesis to reac- tivity and applications. Organic Chemis-

try Frontiers, 5(3), 453-493. https://doi.org/10.1039/c7qo00836h

81. Sowmiah, S., Esperança, J. M. S. S., Rebelo, L. P. N., \& Afonso, C. A. M. (2018). Pyridinium salts: From synthesis to reactivity and applications. Organic Chemistry Frontiers, 5(3), 453-493. https://doi.org/10.1039/c7qo00836h

82. Sun, N., Rodríguez, H., Rahman, M., \& Rogers, R. D. (2011). Where are ionic liquid strategies most suited in the pursuit of chemicals and energy from lignocellulosic biomass? Chemical Communications, 47(5), 1405-1421. https://doi.org/ 10.1039/ c0cc03990j

83. Trulove, P. C., States, U., \& Academy, N. (2014). Ionic Liquid Based Conversion of Biomass to Hydrocarbon Fuels. October

84. Uju, Nakamoto, A., Shoda, Y., Goto, M., Tokuhara, W., Noritake, Y., Katahira, S., Ishida, N., Ogino, C., \& Kamiya, N. (2013). Low melting point pyridinium ionic liquid pretreatment for enhancing enzymatic saccharification of cellulosic biomass. Bioresource Technology, 135, 103108. https://doi.org/10.1016/j.biortech. 2012.06.096

85. Uju, Nakamoto, A., Shoda, Y., Goto, M., Tokuhara, W., Noritake, Y., Katahira, S., Ishida, N., Ogino, C., \& Kamiya, N. (2013). Low melting point pyridinium ionic liquid pretreatment for enhancing enzymatic saccharification of cellulosic biomass. Bioresource Technology, 135, 103$108 . \quad$ https://doi.org/10.1016/ j.biortech.2012.06.096

86. Uju, Nakamoto, A., Shoda, Y., Goto, M., Tokuhara, W., Noritake, Y., Katahira, S., Ishida, N., Ogino, C., \& Kamiya, N. (2013). Low melting point pyridinium ionic liquid pretreatment for enhancing enzy- 
matic saccharification of cellulosic biomass. Bioresource Technology, 135, 103108. https://doi.org/10.1016/j.biortech. 2012.06 .096

87. Usmani, Z., Sharma, M., Gupta, P., Karpichev, Y., Gathergood, N., Bhat, R., \& Gupta, V. K. (2020). Ionic liquid based pretreatment of lignocellulosic biomass for enhanced bioconversion. Bioresource Technology, 304(November 2019), 123003. https://doi.org/10.1016/ j.biortech. 2020.123003

88. Vancov, T., Alston, A. S., Brown, T., \& McIntosh, S. (2012). Use of ionic liquids in converting lignocellulosic material to biofuels. Renewable Energy, 45, 1-6. https://doi.org/10.1016/j.renene.2012.0 2.033

89. Vancov, T., Alston, A. S., Brown, T., \& McIntosh, S. (2012). Use of ionic liquids in converting lignocellulosic material to biofuels. Renewable Energy, 45, 1-6. https://doi.org/10.1016/j.renene.2012.0 2.033

90. Vaniz, W. F. S. (1976). Preview_2.Pdf (pp. 70-72).

https://books.google.com.vn/books?hl= $v i \&|r=\& i d=H S n R p 1 m 3 D| 4 C \& o i=f n d \& p$ $g=P A 1 \& d q=x i p h a s i a+$ setifer + morphology\&ots $=$ FzV5sKOfPQ\&sig $=$ SjTHQyHd

WbkVwc-F5tmqPBdRoac\&redir_esc $=y \# v=$ onepage $\& q=x i p h a s i a \quad s e-$ tifer $\& f=$ false

91. Vaniz, W. F. S. (1976). Preview_2.Pdf (pp. 70-72).

https://books.google.com.vn/books?hl= vi\&Ir=\&id=HSnRp1 m3DI4C\&oi=fnd\&p $g=P A 1 \& d q=x i p h a s i a+$ setifer + morphology\&ots =FzV5sKOfPQ\&sig $=$ SjTHQyHd WbkVwc-F5tmqPBdRoac\&redir_esc $=y \# v=$ onepage $\& q=x i p h a s i a \quad s e-$ tifer\&f $=$ false
92. Vaniz, W. F. S. (1976). Preview_2.Pdf (pp. 70-72).

https://books.google.com.vn/books?hl= vi\&|r=\&id=HSnRp1m3D|4C\&oi=fnd\&p $\mathrm{g}=\mathrm{PA} 1 \& \mathrm{dq}=\mathrm{xiphasia}+$ setifer + morphology\&ots=FzV5sKOfPQ\&sig =SjTHQyHd WbkVwc-F5tmqPBdRoac\&redir_esc $=y \# v=$ onepage $\& q=x i p h a s i a \quad$ setifer\& $\mathrm{f}=$ false

93. Wang, H., Zhu, C., Li, D., Liu, Q., Tan, J., Wang, C., Cai, C., \& Ma, L. (2019). Recent advances in catalytic conversion of biomass to 5-hydroxymethylfurfural and 2, 5-dimethylfuran. Renewable and Sustainable Energy Reviews, 103(December 2018), 227-247. https: //doi.org/10.1016/j.rser.2018.12.010

94. WBA, W. B. A. (2020). GLOBAL BIOENERGY STATISTICS 2020 World Bioenergy Association. 1-64. https://worldbioenergy.org/uploads/201210 WBA GBS 2020.pdf

95. Weerachanchai, P., Su, S., Leong, J., Chang, M. W., Ching, C. B., \& Lee, J. (2012). Bioresource Technology Improvement of biomass properties by pretreatment with ionic liquids for bioconversion process. Bioresource Technology, 111, 453-459. https://doi.org/10.1016/j.biortech.2012. 02.023

96. Weichselbaumer, M. (2014). Pyridinefunctionalized polymeric catalysts for $\mathrm{CO}$ 2 -reduction Lehramt Chemie und Mathematik Eidesstattliche Erkl " arung.

97. Wenten, I. G., Victoria, A. V., Tanukusuma, G., Khoiruddin, K., \& Zunita, M. (2019). Simultaneous clarification and dehydration of crude palm oil using superhydrophobic polypropylene membrane. Journal of Food Engineering, 248(December 2018), 23-27. 
https://doi.org/10.1016/ j.jfoodeng. 2018.12.010

98. Xu, F., Sun, J., Konda, N. V. S. N. M., Shi, J., Dutta, T., Scown, C. D., Simmons, B. A., \& Singh, S. (2016). Transforming biomass conversion with ionic liquids: Process intensification and the development of a high-gravity, one-pot process for the production of cellulosic ethanol. Energy and Environmental Science, 9(3), 10421049.

https://doi.org/10.1039/c5ee02940f

99. Yan, Y., Gu, J., \& Bocarsly, A. B. (2014). Hydrogen bonded pyridine dimer: A possible intermediate in the electrocatalytic reduction of carbon dioxide to methanol. Aerosol and Air Quality Research, 14(2), 515-521. https://doi.org/10.4209/aaqr.2013.06.02 27

100. Yoo, C. G., Pu, Y., \& Ragauskas, A. J. (2017). Ionic liquids: Promising green solvents for lignocellulosic biomass utilization. Current Opinion in Green and Sustainable Chemistry, 5, 5-11. https://doi.org/10.1016/j.cogsc.2017.03. 003

101. Yu, J. Y. (2016). Characterization of Solid Lewis Acids in Biomass Conversion Reactions.

102. Zhang, S., Sun, J., Zhang, X., Xin, J., Miao, Q., \& Wang, J. (2014). Ionic liquid-based green processes for energy production. Chemical Society Reviews, 43(22), 78387869.

https://doi.org/10.1039/c3cs60409h

103. Zunita, M. (2021). Graphene oxide-based nanofiltration for $\mathrm{Hg}$ removal from wastewater: A mini review. Membranes, 11(4). https://doi.org/10.3390/ membranes 11040269

104. Zunita, M., Hastuti, R., Alamsyah, A., Khoiruddin, K., \& Wenten, I. G. (2021).
Ionic Liquid Membrane for Carbon Capture and Separation. Separation \& Purification Reviews, 1-20. https://doi.org/ 10.1080/15422119.2021.1920428

105. Zunita, M., Makertiharta, I. G. B. N., Irawanti, R., Prasetya, N., \& Wenten, I. G. (2018). Graphene Oxide-Inorganic Composite Membrane: A Review. IOP Conference Series: Materials Science and Engineering, 395(1). https://doi.org/10.1088/ 1757-899X/395/1/012005

106. Zunita, M., Makertiharta, I. G. B. N., Saputra, F. A., Syaifi, Y. S., \& Wenten, I. G. (2018). Metal oxide based antibacterial membrane. IOP Conference Series: Materials Science and Engineering, 395(1), 012021. https://doi.org/10.1088/ 1757899X/395/1/012021

107. Zunita, M., Wahyuningrum, D., Bundjali, B., Wenten, I. G., \& Boopathy, R. (2020). Corrosion Inhibition Performances of Imidazole Derivatives-Based New lonic Liquids on Carbon Steel in Brackish Water. Applied Sciences, 10, 7069. https://doi.org/10.3390/app10207069

108. Zunita, M., Wahyuningrum, D., Bundjali, B., Wenten, I. G., \& Boopathy, R. (2020). The performance of 1,3-dipropyl-2-2-(2propoxyphenyl)-4,5-diphenylimidazolium iodide based ionic liquid for biomass conversion into levulinic acid and formic acid. Bioresource Technology, 315(July), 123864. https://doi.org/10.1016/ j.biortech.2020.123864

109. Zunita, M., Wahyuningrum, D., Bundjali, B., \& Wenten, I. G. (2021). A Concise and Efficient Synthesis of Novel Alkylated 2(2-hydroxyphenyl)-4, 5-diphenylimidazole-based Ionic Liquids Using the MAOS Technique. Organic Preparation and Procedures International, 53, 151-156. 
https://doi.org/10.1080/00304948.2020. 1870397

110. Zunita, M., Wahyuningrum, D., Bundjali, B., Wenten, I. G., \& Boopathy, R. (2021). Conversion of Glucose to 5-Hydroxymethylfurfural, Levulinic Acid, and
Formic Acid in 1, 3-Dibutyl-2-(2-butoxyphenyl)-4, 5-diphenylimidazolium lodide-Based Ionic Liquid. Applied Sciences, 11 , 989 https://doi.org/10.3390/app1103098 